\title{
Smallholder Coffee Productivity as Affected by Socioeconomic Factors and Technology Adoption
}

\author{
Daniel M. Wambua $\mathbb{D}^{\mathrm{D}}{ }^{1}$ Bernard M. Gichimu $\mathbb{D}^{2},{ }^{2}$ and Samuel N. Ndirangu' \\ ${ }^{1}$ Department of Agricultural Economics and Extension, University of Embu, P.O. Box 6-60100, Embu, Kenya \\ ${ }^{2}$ Department of Agricultural Resource Management, University of Embu, P.O. Box 6-60100, Embu, Kenya
}

Correspondence should be addressed to Daniel M. Wambua; wambua.daniel@embuni.ac.ke

Received 29 April 2020; Revised 14 January 2021; Accepted 16 February 2021; Published 28 February 2021

Academic Editor: Yong In Kuk

Copyright (c) 2021 Daniel M. Wambua et al. This is an open access article distributed under the Creative Commons Attribution License, which permits unrestricted use, distribution, and reproduction in any medium, provided the original work is properly cited.

\begin{abstract}
Despite the increase in area under coffee in Kenya in the last decade, productivity has been on the decline. Numerous production technologies have been developed through on-station research but there has been limited on-farm research to assess the impact of these technologies at the farm level. On the other hand, smallholder farmers are endowed differently and this would positively or negatively affect the adoption of recommended technologies and hence coffee productivity. This study was carried out to evaluate the effects of socioeconomic factors and technology adoption on smallholder coffee productivity at the farm level. The study employed stratified random sampling where 376 farmers were randomly sampled from six cooperative societies which had been preselected using probability proportional to the size sampling technique. The effects of socioeconomic factors and technology adoption on coffee productivity were analyzed using the stochastic Cobb-Douglas production function. The study revealed that off-farm income, access to credit, type of land tenure, and land size had significant positive effects on coffee productivity. Therefore, coffee farmers should be encouraged to diversify their income sources and to embrace credit financing, as the government reviews land use policies to avail adequate agricultural land. The study further revealed that the adoption of recommended application rates of manure, fungicides, and pesticides had significant positive effects on coffee productivity. The adoption of these technologies should therefore be enhanced among small-scale farmers to improve coffee productivity at the farm level.
\end{abstract}

\section{Introduction}

The economic prosperity of some advanced as well as less developed countries is dependent on agriculture, which is a major source of food, income, and employment [1]. In Kenya, agriculture accounts for $18 \%$ of the total formal employment and directly contributes approximately $26 \%$ of the annual gross domestic product (GDP) [2]. The sector supplies $65 \%$ of Kenya's total exports and is thus the largest contributor of foreign exchange earnings in the country through the export of horticulture, tea, and coffee [3]. Coffee is among the most traded commodities and also among the most consumed beverages in the world [4]. In Kenya, coffee is the fourth leading foreign exchange earner after tourism, tea, and horticulture and contributes about $8 \%$ of the total agricultural output in the country [5].
Despite the increase in area under coffee in Kenya in the last decade, productivity has been on the decline and this has attracted a lot of policy concerns in the country. This has generated research interest towards the development of production technologies aimed at improving coffee yields and quality. However, according to Muzari et al. [6], there is a large gap between the actual productivity of a smallholder farmer and the feasible productivity that is achievable with the available technology. The introduction of innovations has been proposed as one of the many solutions that can potentially improve agricultural performance and boost agricultural productivity [7]. Unfortunately, agricultural productivity may be hindered by the inability of farmers to adopt innovations such as improved production practices, inputs, and varieties [8]. This may result from the inability of the farmers to comply with the conditions associated with 
the adoption of such technologies such as recommended method and period of application.

Coffee productivity can reportedly be increased through expansion of the total acreage under the crop, adoption of scientifically generated technologies, and increased efficiency of the allocation of scarce production resources for output maximization [9]. For example, various studies reported a positive and significant effect of the adoption of Coffee Berry Disease (CBD) and Coffee Leaf Rust (CLR) resistant cultivars on coffee productivity [10-12]. Deviations from the optimal frontier production function in coffee can be due to under- or overutilization of the factors of production and random exogenous shocks such as climate change, uncertainty of factor prices, and market variations [6]. Cheserek and Gichimu [13] noted that climate change had rendered significant proportions of traditional coffee growing zones less suitable for coffee production, thus causing a shift from optimal to suboptimal coffee growing zones, which affects crop yields and quality.

The Kenyan Government has established a research institute known as Coffee Research Institute (CRI) which has conducted extensive on-station research on coffee production and management in the country and recommended various production technologies. These include improved coffee varieties which are released together with their agronomic recommendations including plant spacing, fertilizer application, pest and disease control, and canopy management [5]. However, CRI has conducted limited on-farm research to assess the impact of research recommendations on coffee productivity at the farm level. This is important considering that it is at the farm level where the recommended technologies interact with the prevailing socioeconomic environment. In addition, research centers examine the impacts of one agricultural technology focusing on a single technology adoption with less regard to interdependence among technologies [14]. Moreover, the trials are carried out in either the research stations or demonstration plots with little consideration of the farmer characteristics and dynamics at the farm level. Therefore, there is limited quantitative information on farmer-related or on-farm production constraints and yield gaps.

The objective of this study was to determine the effect of socioeconomic factors and technology adoption on coffee productivity among the smallholder coffee farmers in Embu County, Kenya. The study conducted an indepth analysis of total factor productivity through optimum input allocation in combination with the socioeconomic characteristics among the smallholder coffee farmers. In order to determine the impact of the released technologies on productivity, the study examined the effect of these recommended technologies and socioeconomic characteristics on coffee yields at the farm level. The findings provide clear understanding of how the technical factors interact with socioeconomic factors at the farm level and their ultimate effects on coffee productivity. This will guide the policymakers to put in place sustainable intervention measures to ensure that released technologies will have the desired impact on productivity. The study first sought to assess the socioeconomic factors and levels of adoption of recommended technologies among smallholder coffee farmers. This was followed by an empirical analysis of how socioeconomic factors and technology adoption affects coffee productivity.

\section{Materials and Methods}

2.1. Description of the Study Site. The study was conducted in Manyatta and Runyenjes subcounties in Embu County, Kenya, where most of the marketed coffee is produced by smallholder farmers. The area is located in Upper Midland (UM) zone, 2-3 agroecological zones, within an altitude range from 1600 to $1800 \mathrm{~m}$ above sea level [15]. The rainfall pattern in the study area is bimodal but the annual quantity ranges between 1120 and $1495 \mathrm{~mm}$. The average temperatures range from a minimum of $12^{\circ} \mathrm{C}$ in July to a maximum of $30^{\circ} \mathrm{C}$ in March and September [5].

2.2. Sampling Procedure and Sample Size. The study applied multistage stratified random sampling to select the farmers to be interviewed. Two cooperative societies were randomly selected from Runyenjes subcounty and four from Manyatta subcounty. Probability proportional to size sampling criteria was employed to sample the respondents from the farmers who were members of the selected cooperative societies. The sample size for the study was 376 smallholder coffee farmers selected using the formula of Cochran [16] as described as follows:

$$
n_{o}=\frac{Z^{2} p q}{e^{2}}
$$

where $n 0$ is the required sample size, $Z$ is the $t$ value at $95 \%$ confidence level from normal table (1.96), $p$ is the probability that respondent has characteristic being measured, $q$ is $(1-p)$ probability that respondent has no characteristic being measured, and $e$ is $5 \%$ level of significance.

Assuming 50\% probability that the respondent had the characteristic being measured, the sample size was calculated as follows:

$$
n_{o}=\frac{(1.96)^{2}(0.5)(0.5)}{(0.05)^{2}}=384 \text {. }
$$

Since the estimated target population was only 20,000 farmers, the sample size was adjusted using the equation recommended [16] for small size finite population correction as follows:

$$
\begin{aligned}
& n=\frac{n_{o}}{1+\left(\left(n_{o}-1\right) / N\right)} \\
& n=\frac{384}{1+((384-1) / 20,000)}=376 \text { farmers. }
\end{aligned}
$$

The number of farmers from each cooperative society was determined using the following formula applied by [15]: 


$$
k=\frac{p}{M} * 376
$$

where $k$ is the number of farmers to be interviewed, $p$ is the number of members in a cooperative society, and $M$ is the total number of smallholder coffee farmers in the selected cooperative societies.

2.3. Data Collection. The primary data were obtained from sampled farmers using structured questionnaires covering one crop season (one production year). The key primary variables collected were coffee output (yield) versus level of adoption of recommended technologies including improved varieties, proper tree spacing, types and rates of fertilizers, pesticides and fungicides applied, and method of canopy management adopted. Data were also collected based on the socioeconomic factors of the respondents such as gender, age, family size, farming experience, and availability of offfarm income. The study was based on the firm theory that the main objective of smallholder farmers is profit maximization through cost minimization and improved production.

2.4. Data Analysis. Descriptive statistics were used to analyze the demographic characteristics of the farmers that were hypothesized to influence coffee productivity. To determine the effect of recommended technologies and socioeconomic factors on coffee productivity, the stochastic Cobb-Douglas production function was used as proposed by Aigner et al. [17] and Seyoum et al. [18]. In this study, the Cobb-Douglas production model was specified as

$$
\ln Y=\ln \beta_{o}+\sum_{i} \beta_{i} \ln X_{i}+\sum_{j} \beta_{j} Z_{j}+\sum_{k} \beta_{k} D_{k}+\varepsilon,
$$

where $\ln$ is the natural logarithm; $Y$ is the observed coffee output; $\beta_{0}, \beta_{i}, \beta_{j}$, and $\beta_{k}$ are the vector parameters estimated; $X_{i}$ is the number of inputs; $Z_{j}$ is the values of socioeconomic factors; $D_{k}$ is the dummy variables for the adoption of recommended technologies ( 1 denotes adopted; 0 denotes nonadoption); and $\varepsilon$ is an error term. The Cobb-Douglas production model was preferred because it has the advantage of allowing for statistical inference and the estimated coefficients are easy to interpret.

\section{Results}

3.1. Demographic Characteristics of the Respondents. The social characteristics of the respondents are summarized in Table 1. Out of the 376 farmers that were interviewed, $74.7 \%$ were male, while $25.3 \%$ were female. The majority $(84.6 \%)$ of the farmers were aged between 41 and 60 years with farmers below 30 years constituting only $1.1 \%$. The household size ranged from 1 to 9 family members with the majority (69.7\%) having 4-6 members. Most of the farmers $(75.8 \%)$ had attained secondary education and above with only $3.2 \%$ lacking formal education. The majority (90.1\%) of the respondents had 10 years and above of experience in coffee farming with only $9.8 \%$ having less than 10 years of farming experience (Table 1).

3.2. Economic Factors of the Respondents. Table 2 shows descriptive statistics of the selected economic characteristics of the respondents. The majority (77.6\%) of the sampled farmers owned one acre of land and below and most of them (83\%) had allocated half an acre and below to coffee production. Only $14.1 \%$ of the sampled respondents were purely farmers with the rest $(85.9 \%)$ earning some off-farm income from other economic activities. Less than half (43.4\%) of the sampled respondents had land ownership rights in form of land title deed, implying that the majority of the respondents did not have security of land tenure (Table 2). The majority of the respondents $(86.4 \%)$ received extension services either from their cooperative society $(77.7 \%)$ or from research institutions $(8.8 \%)$. The number of extension visits ranged from none to three but most of the respondents (49.5\%) were visited twice. Credit facilities for financing coffee farming were accessible to $70.5 \%$ of the sampled farmers but $29.5 \%$ of the farmers did not access credit due to various reasons (Table 2). Most of those who could not access credit cited uncertainty in coffee returns as the major hindrance.

3.3. Appropriation of Production Inputs. Input use was found to vary with the scale of production and farm size and among different farmers (Table 3 ). These variations were in both the type of input used and the application rates. Only $38 \%$ of the farmers used the recommended rate of NPK fertilizer per tree while $36 \%$ used more than the recommended rate. Most of the farmers $(41.2 \%)$ applied more than the recommended rate of CAN fertilizer per tree while $35.4 \%$ applied the recommended rate of CAN. The majority of the farmers (90\%) applied manure at the recommended rate of $20-40 \mathrm{~kg}$ per tree. Only $33.5 \%$ of the farmers who were growing traditional varieties that are susceptible to CBD and CLR applied fungicides at the recommended rate of 2-3 liters or $\mathrm{kg}$ per acre. The majority of them (51.6\%) exceeded the recommended application rate of fungicides. However, this study established that the majority of the farmers $(52.1 \%)$ used the recommended pesticide rate of 1-2 liters per acre (Table 3).

3.4. Coffee Varieties and Their Management. Table 4 shows the descriptive statistics of agronomic practices of coffee management. The recommended coffee varieties for the study area were Ruiru 11 and Batian due to their production potentials and resistance to major coffee diseases. However, the majority of the farmers $(67.2 \%)$ were still dependent on the traditional varieties (SL28, SL34, and K7) that are relatively less yielding and susceptible to the major coffee diseases. A high proportion of farmers (59.3\%) had practiced a change of cycle on their coffee trees in the last ten years. Annual coffee pruning was a popular practice adopted by 98.4\% of the farmers but tree capping was not a common 
TABLe 1: Frequencies of key social characteristics of the respondents.

\begin{tabular}{|c|c|c|c|}
\hline Social factors & Description & Frequency & Percent \\
\hline \multirow{2}{*}{ Gender of the farmer } & Male & 281 & 74.7 \\
\hline & Female & 95 & 25.3 \\
\hline \multirow{5}{*}{ Age of the farmer } & $18-30$ years & 4 & 1.1 \\
\hline & $31-40$ years & 26 & 6.9 \\
\hline & $41-50$ years & 158 & 42 \\
\hline & $51-60$ years & 160 & 42.6 \\
\hline & 61 and above & 28 & 7.4 \\
\hline \multirow{3}{*}{ Household size } & $1-3$ & 74 & 19.7 \\
\hline & $4-6$ & 262 & 69.7 \\
\hline & $7-9$ & 40 & 10.6 \\
\hline \multirow{4}{*}{ Level of formal education } & None & 12 & 3.2 \\
\hline & Up to primary school & 79 & 21 \\
\hline & Up to secondary school & 245 & 65.2 \\
\hline & Up to tertiary colleges & 40 & 10.6 \\
\hline \multirow{3}{*}{ Experience in coffee farming } & 10 years & 37 & 9.8 \\
\hline & $10-20$ years & 231 & 61.4 \\
\hline & Above 20 years & 108 & 28.7 \\
\hline
\end{tabular}

TABle 2: Descriptive statistics of economic factors of the sampled farmers.

\begin{tabular}{|c|c|c|c|}
\hline Economic factors & Description & Frequency & Percent \\
\hline \multirow{4}{*}{ Total land size } & Less than 0.5 acres & 111 & 29.5 \\
\hline & $0.5-1.0$ acres & 181 & 48.1 \\
\hline & $1.01-1.5$ acres & 39 & 10.4 \\
\hline & More than 1.5 acres & 45 & 12 \\
\hline \multirow{4}{*}{ Land size under coffee } & Less than 0.25 acres & 153 & 40.7 \\
\hline & $0.25-0.5$ acres & 159 & 42.3 \\
\hline & $0.51-1.0$ acres & 51 & 13.6 \\
\hline & More than 1.0 acres & 13 & 3.5 \\
\hline \multirow{4}{*}{ Monthly off-farm income } & Less than $10,000 \mathrm{Kes}$ & 109 & 29 \\
\hline & $10,000-20,000 \mathrm{Kes}$ & 188 & 50 \\
\hline & More than $20,000 \mathrm{Kes}$ & 26 & 6.9 \\
\hline & No off-farm income & 53 & 14.1 \\
\hline \multirow{2}{*}{ Land ownership } & With title deed & 163 & 43.4 \\
\hline & Without title deed & 213 & 56.6 \\
\hline \multirow{3}{*}{ Access to extension services } & From cooperative society & 292 & 77.6 \\
\hline & From research institutions & 33 & 8.8 \\
\hline & No extension & 51 & 13.6 \\
\hline \multirow{4}{*}{ Extension visits per season } & Once & 85 & 22.6 \\
\hline & Twice & 186 & 49.5 \\
\hline & Thrice & 54 & 14.4 \\
\hline & None & 51 & 13.6 \\
\hline \multirow{2}{*}{ Credit access } & Yes & 265 & 70.5 \\
\hline & No & 111 & 29.5 \\
\hline
\end{tabular}

practice as only $15.4 \%$ of the farmers were practicing it. The majority of the farmers $(94.4 \%)$ maintained 2 heads per stem as recommended.

3.5. Coffee Production. Descriptive statistics for coffee production across the sampled farms are shown in Table 5. The number of coffee trees among the sampled farmers ranged from 30 to 2000 trees which averaged 262 trees per farmer. The cherry production ranged from 100 to $12,000 \mathrm{~kg}$ which averaged $1106.24 \mathrm{~kg}$ while buni (dried cherry) production ranged from 1 to $430 \mathrm{~kg}$ which averaged $27.85 \mathrm{~kg}$ per farm. The results revealed variations in coffee productivity with cherry output per tree ranging from 0.62 to $20 \mathrm{~kg}$ which averaged $4.66 \mathrm{~kg}$. On the other hand, cherry output per acre ranged from 82 to $21,368 \mathrm{~kg}$ with a mean of $2433.75 \mathrm{~kg}$ (Table 5).

3.6. Effect of Socioeconomic Factors and Technology Adoption on Coffee Productivity. A stochastic Cobb-Douglas production function was used to show the effect of socioeconomic 
TABLE 3: Descriptive statistics for fertilizer and manure application rates.

\begin{tabular}{|c|c|c|c|}
\hline $\begin{array}{l}\text { Farm inputs per } \\
\text { application }\end{array}$ & Description & Frequency & Percent \\
\hline \multirow{4}{*}{ NPK rate per tree } & $0-99$ & 61 & 16.2 \\
\hline & $100-199$ & 37 & 9.8 \\
\hline & $200-300$ & 143 & 38.0 \\
\hline & More than $300 \mathrm{~g}$ & 135 & 36 \\
\hline \multirow{4}{*}{ CAN rate per tree } & $0-99 \mathrm{~g}$ & 51 & 13.6 \\
\hline & $100-199 \mathrm{~g}$ & 36 & 9.8 \\
\hline & $200-300 \mathrm{~g}$ & 134 & 35.4 \\
\hline & More than $300 \mathrm{~g}$ & 155 & 41.2 \\
\hline \multirow{3}{*}{$\begin{array}{l}\text { Amount of manure per } \\
\text { tree }\end{array}$} & Less than $20 \mathrm{~kg}$ & 22 & 5.8 \\
\hline & $20-40 \mathrm{Kg}$ & 338 & 90.0 \\
\hline & $\begin{array}{l}\text { More than } \\
40 \mathrm{Kg}\end{array}$ & 16 & 4.2 \\
\hline \multirow{3}{*}{$\begin{array}{l}\text { Amount of fungicides per } \\
\text { acre }\end{array}$} & Less than $2 \mathrm{~L} / \mathrm{Kg}$ & 56 & 14.9 \\
\hline & $2-3 \mathrm{~L} / \mathrm{Kg}$ & 126 & 33.5 \\
\hline & $\begin{array}{l}\text { More than } \\
3 \mathrm{~L} / \mathrm{Kg}\end{array}$ & 194 & 51.6 \\
\hline \multirow{3}{*}{$\begin{array}{l}\text { Amount of pesticides per } \\
\text { acre }\end{array}$} & Less than $1 \mathrm{~L}$ & 69 & 18.4 \\
\hline & $1-2 \mathrm{~L}$ & 196 & 52.1 \\
\hline & More than $2 \mathrm{~L}$ & 111 & 29.5 \\
\hline
\end{tabular}

TABle 4: Descriptive statistics of coffee management practices among farmers.

\begin{tabular}{lccc}
\hline Tree management & Categories & Frequency & Percent \\
\hline \multirow{4}{*}{ Coffee variety } & Ruiru 11 & 110 & 29.3 \\
& Batian & 13 & 3.5 \\
& SL 28 & 220 & 58.5 \\
& SL 34 & 25 & 6.6 \\
& K7 & 8 & 2.1 \\
\hline \multirow{2}{*}{ Change of cycle } & Yes & 223 & 59.3 \\
& No & 153 & 40.7 \\
\hline \multirow{2}{*}{ Pruning } & Yes & 370 & 98.4 \\
& No & 6 & 1.6 \\
\hline \multirow{2}{*}{ Capping } & Yes & 58 & 15.4 \\
& No & 318 & 84.6 \\
\hline \multirow{4}{*}{ Heads per stem } & 1 & 9 & 2.4 \\
& 2 & 244 & 64.9 \\
& 3 & 111 & 29.5 \\
& Above 3 & 12 & 3.2 \\
\hline
\end{tabular}

factors and technology adoption on coffee productivity (Table 6). Multiple regression analysis revealed that the coefficient for farmers' engagement in off-farm income-earning activities was positive (0.080) and significant at 5\% level $(P=0.028)$, implying that engagement in off-farm activities increases coffee yield by about $8 \%$. Land ownership had a positive (0.091) and significant coefficient at 5\% level $(P=0.011)$, implying that owning land increases coffee output by $9.1 \%$. The coefficient for land size under coffee was positive $(0.353)$ and highly significant at $1 \%$ level $(P=0.001)$, implying that increasing the land size by 10 percent increases coffee output by $3.5 \%$. Access to credit had a positive $(0.074)$ and significant coefficient at 5\% level $(P=0.030)$, implying that availability of credit increases coffee output by $7.4 \%$.
TABle 5: Descriptive statistics for coffee production in the study area.

\begin{tabular}{lccccc}
\hline Production & Min & Max & Mean & $\begin{array}{c}\text { Std. } \\
\text { error }\end{array}$ & Std. deviation \\
\hline $\begin{array}{l}\text { Trees owned } \\
\text { (no) }\end{array}$ & 30 & 2000 & 262 & 9.923 & 192.408 \\
$\begin{array}{l}\text { Cherry } \\
\text { output/tree (kg) }\end{array}$ & 0.62 & 20 & 4.6624 & 0.13291 & 2.57716 \\
$\begin{array}{l}\text { Cherry output } \\
\text { (kg/yr) }\end{array}$ & 100 & 12000 & 1106.24 & 55.551 & 1077.18 \\
$\begin{array}{l}\text { Buni output } \\
\text { (kg/yr) }\end{array}$ & 1 & 430 & 27.85 & 2.194 & 42.538 \\
$\begin{array}{l}\text { Cherry output/ } \\
\text { acre (kg) }\end{array}$ & 82 & 21368 & 2433.75 & 104.320 & 2022.838 \\
\hline
\end{tabular}

On technology adoption, the coefficient for the recommended manure rate was positive $(0.196)$ and significant at $1 \%$ level $(P=0.001)$, implying that the coffee yield for adopters of recommended manure rate was 19.6 percent higher than that of nonadopters. The coefficient for recommended rate of fungicides was also positive (0.118) and significant at $5 \%$ level $(P=0.010)$, implying that the yield obtained by adopters of recommended fungicide rate was $11.8 \%$ higher than that obtained by nonadopters. In addition, the recommended rate of pesticides had a positive (0.088) and significant coefficient at 5\% level $(P=0.012)$, indicating that the yield obtained by adopters of recommended fungicide rate was $8.8 \%$ higher than that obtained by nonadopters. The absolute $t$ values for significant variables were relatively higher indicating an increase in the difference between the variables and the null hypothesis. Variance Inflation Factor (VIF) was lower than 5 for all predictor variables, implying significant multicollinearity among independent variables used in the model (Table 6).

\section{Discussion}

Most socioeconomic factors including gender and age of the farmer, education level, coffee farming experience, household size, and extension services were not found to significantly influence coffee productivity. However, off-farm income, access to credit, land ownership (tenure), and land size had a significant effect on coffee productivity. The study revealed that $85.9 \%$ of the farmers were earning some offfarm income and $70.5 \%$ were accessing credit facilities. These two factors may have played a significant role in cushioning farmers' financial constraints and ability to mitigate costs and risks associated with the adoption of new technologies, thus reducing crop failures and increasing productivity. Access to credit and off-farm income also increases the ability of the farmer to access key farm inputs at the required time and increases household risk-bearing ability against production and market risks. The significant effect of off-farm income on productivity has also been reported in other studies [19-21]. Access to credit had a positive and significant elasticity in explaining variations in coffee yield. The significant effect of credit accessibility on farm productivity was also reported in previous studies 
TABLE 6: Multiple regression for socioeconomic and technical factors affecting coffee productivity.

\begin{tabular}{|c|c|c|c|c|c|}
\hline Depender & Beta & SE & $t$ & Sig & VIF \\
\hline Cons & 924 & .618 & 7.972 & 0.001 & \\
\hline Gende & 46 & 062 & 1356 & .178 & 27 \\
\hline $\begin{array}{l}\text { Age of the farmer } \\
\text { (years) }\end{array}$ & $=0.31$ & 0.037 & -0.76 & 0.444 & .88 \\
\hline Level of education & -0.029 & 0.037 & -0.803 & 0.423 & 1.539 \\
\hline g experience & 0.01 & 0044 & 04 & 0662 & 57 \\
\hline 11 i & 0.012 & 0.042 & 0.352 & 0.725 & 1.398 \\
\hline & 080 & 0.064 & 3 & $.028^{* *}$ & 1.539 \\
\hline $\begin{array}{l}\text { Lan } \\
\text { (ten }\end{array}$ & 0.091 & 0.047 & 2.579 & $0.011^{* *}$ & 1.477 \\
\hline Acc & 6 & 072 & 1.383 & 0 & 37 \\
\hline & 035 & .046 & 7 & $0.001^{* * *}$ & 2.631 \\
\hline access $($ yes $=1$; & 0.074 & 0.054 & 218 & $0.030^{* *}$ & 1.34 \\
\hline 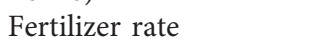 & 060 & .046 & 1.955 & 0 & 1.472 \\
\hline & 0.196 & 0.068 & 5.580 & $0.001^{* * *}$ & 1.474 \\
\hline & 0.118 & 0.061 & 2.619 & $0.010^{* *}$ & 2.409 \\
\hline & & 0.040 & & 0.0 & .432 \\
\hline & -0. & 0.044 & -0 . & 0 & 1.290 \\
\hline & 0.001 & 0.044 & & 0.964 & 1.224 \\
\hline & & 0.179 & 0.3 & & 1.185 \\
\hline & & & & & 1.267 \\
\hline Heads per stem & -0.022 & 0.045 & -0.654 & 0.515 & 1.359 \\
\hline
\end{tabular}

Highlighted factors were significant at ${ }^{* * *} 1 \%$ and ${ }^{* *} 5 \%$

$[19,22,23]$. Access to credit and availability of off-farm income would also finance investment in capital-intensive technologies for increased production efficiency and productivity per unit area to avoid diseconomies of scale.

Land size is an issue of concern in the study area as the majority of the sampled farmers have less than one acre of land. Land size is assumed to have a direct influence on the size of the coffee farm as farmers with bigger land sizes are able to allocate more land to coffee. The increase in land size increases the scale of production and motivates the farmers to adopt new technologies, hence increasing coffee productivity. Bigger land sizes would also allow some trials on new technologies without affecting the scale of the main crop hence promoting adoption. Studies by Gebeyehu [10] and Senkondo et al. [24] also reported a significant effect of land size on coffee productivity. Chepng'etich et al. [25] and Ng'ombe [26] also made a similar observation on sorghum and maize, respectively. However, the studies by Minai et al. [20] and Musaba and Bwacha [23] found the land size to be negatively related to coffee and maize productivity, respectively. Apart from land size, ownership was also found to have a positive significant influence on coffee productivity. Challa and Tilahun [21], Musaba and Bwacha [23], and Cherukut et al. [27] also reported significant effects of land tenure on farm productivity. Land ownership allows the farmers to make long-term production decisions and facilitate access to credit by offering the land as collateral.

Although most farmers had adopted the recommended or higher rates for all the inputs that were sampled, most of them had no significant effect on coffee productivity apart from manure, fungicides, and pesticides. This was attributed to the fact that farmers are driven by output maximization and would be motivated to use high-yielding methodologies that would guarantee high productivity but at a relatively lower cost. The significant effect of organic manure on coffee productivity was also reported by Gebeyehu [10], Chemura et al. [28, 29], and Dzung et al. [30]. Increased usage of organic manure increases plant height and stem thickening resulting in increased production [30]. Organic soil fertility management is among the important attributes of sustainable and climate-smart agriculture through the improvement of the physicochemical and biological soil properties [10]. The use of organic manure improves soil organic matter which enhances moisture retention as a climate change strategy in water-stressed areas [29]. In addition, organic manure causes increased microbial activity and availability of macronutrients in the soil [29]. However, Mignouna et al. [22] reported the negative effect of manure use on maize productivity explained but attributed it to inappropriate application rates.

This study established that the majority of the farmers $(62.7 \%)$ in the study area were still growing traditional varieties that are susceptible to fungal diseases such as CBD and CLR. This necessitated the use of fungicides to control these diseases. The application of fungicides at the recommended rates had a positive and significant effect on coffee yield. Positive interaction of fungicides and coffee yields has been reported in several previous studies [10, 24, 31]. Apart from controlling the fungal diseases, copper-based fungicides enhance leaf retention, thus promoting chlorophyll process and nutrient uptake, resulting in healthy tree growth and high marketable yields [32]. An amount of pesticide used was found to be positively related to coffee yields in the study area. A similar observation was made by Gebeyehu [10], Lechenet et al. [31], Popp et al. [33], and Ngeywo et al. [34]. Coffee is susceptible to more than 850 species of insect pests including leaf miners, berry moths, berry borers, stem borers, thrips, and aphids [35]. Some of them like the berry borer can cause bean yield losses of 30-35\%. Others like the stem borers may lead to the death of the coffee tree but most of them only weaken the plant, resulting in yield reduction [35]. Some insect pests also act as vectors for the transmission of coffee diseases. The appropriate use of pesticides in coffee production is therefore expected to increase the yields and quality of coffee, thus improving productivity per unit area.

Cherry yields in the study area averaged $4.67 \mathrm{~kg}$ per tree which was slightly higher than the current national average of $4.26 \mathrm{~kg}$ for traditional varieties and $10 \mathrm{~kg}$ per tree for the improved varieties [36]. Coffee production was hypothesized to be a function of factor inputs, recommended technologies, and socioeconomic characteristics in the farm environment. The study established that the majority of the farmers had adopted the recommended or higher rates of application for all the farm inputs that were sampled. The low yields can therefore be attributed to the low adoption of the improved varieties since only $29.3 \%$ and $3.5 \%$ of the sampled farmers were growing Ruiru 11 and Batian varieties, 
respectively. Low yields can also be caused by the untimely application of farm inputs, poor method of application, or wrong choice of inputs especially fungicides and pesticides. For effective and sustainable management of CBD and CLR, Alworah and Gichuru [32] recommended timely fungicide application, proper choice of chemicals, and adoption of good agricultural practices. The low yields may also be attributed to climate change effects which include changes in rainfall patterns and increase in diurnal temperatures, both of which have a significant influence on the dynamics of pests and diseases [37].

\section{Conclusions}

This study demonstrated variations in technology adoption and socioeconomic factors of the sampled farmers. Consequently, there were significant variations in coffee productivity among small-scale farmers. Adoption of the recommended application rates of manure, fungicides, and pesticides had a significant positive effect on coffee productivity. The study therefore recommends the adoption of these and other recommended technologies for improved coffee productivity at the farm level. The policymakers should therefore put the necessary measures in place to persuade the farmers to adopt recommended technologies for improved coffee productivity. The study established that the availability of off-farm income, access to credit, adequate land size, and confidence of land ownership have a pivotal role in enhancing the adoption of recommended technologies at the farm level. Coffee farmers should therefore be encouraged to diversify their income sources and to embrace credit financing. On the other hand, the government should review land use policies and land tenure systems to avail adequate agricultural land and for long-term investments.

\section{Data Availability}

Most of the data used to support the findings of this study are included in the paper. Additional data are available from the corresponding author upon request.

\section{Conflicts of Interest}

The authors declare that there are no conflicts of interest regarding the publication of this paper.

\section{Acknowledgments}

The authors are grateful to the management and farmers of the six cooperative societies in Embu County which were sampled in this study. These are Gakundu, Muramuki, Kibugu, and Rianjagi Farmers' Cooperative Societies in Manyatta subcounty and Kagaari South and Kiangangwa Farmers' Cooperative Societies in Runyenjes subcounty. This study was partially funded by the University of Embu, Kenya.

\section{References}

[1] L. Praburaj, "Role of agriculture in the economic development of a country," Shanlax International Journal of Commerce, vol. 6, no. 3, pp. 1-5, 2018.

[2] H. K. Mohajan, "Food and nutrition scenario of Kenya," American Journal of Food and Nutrition, vol. 2, no. 2, pp. 28-38, 2014.

[3] E. K. Mugweru, S. Odhiambo, and S. Nyandemo, "Determinants of coffee production in the Kenyan economy," Journal of Agriculture Policy, vol. 1, no. 1, pp. 37-57, 2016.

[4] R. A. Balgah, "Factors influencing coffee farmers' decisions to join cooperatives," Sustainable Agriculture Research, vol. 8, no. 1, pp. 42-58, 2019.

[5] D. M. Wambua, S. N. Ndirangu, L. K. Njeru, and B. M. Gichimu, "Effects of recommended improved crop technologies and socio-economic factors on coffee profitability among smallholder farmers in Embu County, Kenya," African Journal of Agricultural Research, vol. 14, no. 34, pp. 1957-1966, 2019.

[6] W. Muzari, W. Gatsi, and S. Muvhunzi, "The impacts of technology adoption on smallholder agricultural productivity in sub-saharan Africa: a review," Journal of Sustainable Development, vol. 5, no. 8, pp. 69-77, 2012.

[7] I. Adofu, S. O. Shaibu, and S. Yakubu, "The economic impact of improved agricultural technology on cassava productivity in Kogi state of Nigeria," International Journal of Food and Agricultural Economics, vol. 1, no. 1, pp. 63-74, 2013.

[8] A. Shimeles, A. Verdier-Chouchane, and A. Boly, Building a Resilient and Sustainable Agriculture in Sub-Saharan Africa, Springer International Publishing AG, Cham, Switzerland, 978-3-319-76222-7, 2018.

[9] T. F. Bocher and F. Simtowe, "Profit efficiency analysis among groundnut farmers from Malawi," Journal of Development and Agricultural Economics, vol. 9, no. 10, pp. 278-288, 2017.

[10] M. G. Gebeyehu, "The impact of technology adoption on agricultural productivity and production risk in Ethiopia: evidence from rural Amhara household survey," Open Access Library Journal, vol. 3, no. 2, 2016.

[11] V. Kamau, J. Ateka, R. Mbeche, and M. M. Kavoi, “Assessment of technical efficiency of smallholder coffee farming enterprises in Muranga, Kenya," Journal of Agriculture, Science and Technology, vol. 18, no. 1, pp. 1-12, 2017.

[12] H. van der Vossen, B. Bertrand, and A. Charrier, "Next generation variety development for sustainable production of arabica coffee (Coffea arabica L.): a review," Euphytica, vol. 204, no. 2, pp. 243-256, 2015.

[13] J. J. Cheserek and B. M. Gichimu, "Drought and heat tolerance in coffee: a review," International Research Journal of Agricultural Science and Soil Science, vol. 2, no. 12, pp. 498-501, 2012.

[14] M. Kassie, P. Marenya, Y. Tessema et al., "Measuring farm and market level economic impacts of improved maize production technologies in Ethiopia: evidence from panel data," Journal of Agricultural Economics, vol. 69, no. 1, pp. 76-95, 2018.

[15] S. Ndirangu, S. Mbogoh, and O. Mbatia, "Effects of land fragmentation on food security in three agro-ecological zones of Embu County in Kenya," Asian Journal of Agricultural Extension, Economics \& Sociology, vol. 18, no. 4, pp. 1-9, 2017.

[16] W. G. Cochran, Sampling Techniques, E. Grebenik and C. A. Moser, Eds., Statistical Surveys, New York, NY, USA, 1963. 
[17] D. Aigner, C. A. K. Lovell, and P. Schmidt, "Formulation and estimation of stochastic frontier production function models," Journal of Econometrics, vol. 6, no. 1, pp. 21-37, 1977.

[18] E. Seyoum, G. E. Battese, and E. M. Fleming, "Technical efficiency and productivity of maize producers in eastern Ethiopia: a study of farmers within and outside the SasakawaGlobal 2000 project," Agricultural Economics, vol. 19, no. 3, pp. 341-348, 1998.

[19] M. A. Akudugu, E. Guo, and S. K. Dadzie, "Adoption of modern agricultural production technologies by farm households in Ghana: what factors influence their decisions," Journal of Biology, Agriculture and Healthcare, vol. 2, no. 3, pp. 1-14, 2012.

[20] J. Minai, N. Nyairo, and P. Mbataru, "Analysis of socioeconomic factors affecting the yields of smallholder coffee farmers in Kirinyaga County, Kenya," Journal of Agricultural and Crop Research, vol. 2, no. 12, pp. 228-235, 2014.

[21] M. Challa and U. Tilahun, "Determinants and impacts of modern agricultural technology adoption in west Wollega: the case of Gulliso District," Journal of Biology, Agriculture and Healthcare, vol. 4, no. 20, pp. 63-78, 2014.

[22] D. B. Mignouna, K. Mutabazi, E. M. Senkondo, and V. M. Manyong, "Adoption of a new maize and production efficiency in western Kenya," in Proceedings of Joint 3rd African Association of Agricultural Economists and 48th Agricultural Economists Association of South Africa Conference, Cape Town, South Africa, September 2010.

[23] E. Musaba and I. Bwacha, "Technical efficiency of small scale maize production in Masaiti district, Zambia: a stochastic frontier approach," Journal of Economics and Sustainable Development, vol. 5, no. 4, pp. 104-111, 2014.

[24] Y. H. Senkondo, F. M. G. Tack, and E. Semu, "Copper accumulations in soils, coffee, banana, and bean plants following copper-based fungicides in coffee farms in Arusha and Kilimanjaro regions, Tanzania," Communications in Soil Science and Plant Analysis, vol. 45, no. 15, pp. 2032-2045, 2014.

[25] E. Chepng'etich, S. O. Nyamwaro, E. K. Bett, and K. Kizito, "Factors that influence technical efficiency of sorghum production: a case of small holder sorghum producers in lower eastern Kenya," Advances in Agriculture, vol. 2015, Article ID 861919, 11 pages, 2015.

[26] J. N. Ng'ombe, "Technical efficiency of smallholder maize production in Zambia: a stochastic meta-frontier approach," Agrekon, vol. 56, no. 4, pp. 347-365, 2017.

[27] S. Cherukut, J. Karungi, J. B. Tumuhairwe, and J. BonabanaWabbi, "Influence of mountainous ecosystems in the production of Arabica coffee," RUFORUM Working Document Series, vol. 14, no. 2, pp. 355-360, 2016, (ISSN 1607-9345).

[28] A. Chemura, C. Mahoya, and D. Kutywayo, "Effect of organic nursery media on germination and initial growth of coffee seedlings," in Proceedings of 23rd International Conference on Coffee Science, Association for Science and Information on Coffee (ASIC), Bali, Indonesia, October 2010.

[29] A. Chemura, "The growth response of coffee (Coffea arabica L) plants to organic manure, inorganic fertilizers and integrated soil fertility management under different irrigation water supply levels," International Journal of Recycling of Organic Waste in Agriculture, vol. 3, no. 59, pp. 1-9, 2014.

[30] N. A. Dzung, T. T. Dzung, and V. T. P. Khanh, "Evaluation of coffee husk compost for improving soil fertility and sustainable coffee production in rural central highland of Vietnam," Resources and Environment, vol. 3, no. 4, pp. 77-82, 2013.
[31] M. Lechenet, F. Dessaint, G. Py, D. Makowski, and N. MunierJolain, "Reducing pesticide use while preserving crop productivity and profitability on arable farms," Nature Plants, vol. 3, no. 17008, pp. 1-6, 2017.

[32] G. O. Alwora and E. K. Gichuru, "Advances in the management of coffee berry disease and coffee leaf rust in Kenya," Journal of Renewable Agriculture, vol. 2, no. 1, pp. 5-10, 2014.

[33] J. Popp, K. Pető, and J. Nagy, "Pesticide productivity and food security. A review," Agronomy for Sustainable Development, vol. 33, no. 1, pp. 243-255, 2013.

[34] J. Ngeywo, A. Shitandi, E. Basweti, and L. Agasa, "Effect of farm succession and farm inputs use on coffee productivity in Kisii County, South Western Kenya," Asian Journal of Agricultural Extension, Economics \& Sociology, vol. 5, no. 2, pp. 69-75, 2015.

[35] J. F. Barrera, "Coffee pests and their management," in Encyclopedia of Entomology, J. L. Capinera, Ed., Springer, Dordrecht, Netherlands, 2008.

[36] ICO and AFA, "Country coffee profile: Kenya," in Proceedings of International Coffee Organization and Agriculture and Food Authority-Coffee Directorate, 124th Session of the International Coffee Council, Nairobi, Kenya, March 2019.

[37] J. Jaramillo, E. Muchugu, F. E. Vega, A. Davis, C. Borgemeister, and A. Chabi-Olaye, "Some like it hot: the influence and implications of climate change on coffee berry borer (Hypothenemus hampei) and coffee production in East Africa," PLoS ONE, vol. 6, no. 9, p. e24528, 2011. 